\title{
TAXATION OF PRIVATE FOUNDATIONS AND GAME THEORY
}

\author{
Urmas Kaarlep \\ Estonian Business School
}

\begin{abstract}
On a global level, the high net worth population is expanding, and the wealth of high net worth individuals (HNWI) is increasing rapidly. For various reasons, high net worth families and individuals are searching for vehicles to assist them in safeguarding and conveniently managing their wealth. Private foundations represent one useful avenue for achieving this end, and the use of private foundations has become increasingly popular in recent years, particularly in European countries. Many countries have laws which regulate private foundations and several are looking for adjusting or introducing legislation. In this article I have looked at different options for taxation of private foundations and analysed what would be the best approach from the game theory point of view. The article comes to a conclusion that at the Nash equilibrium countries give tax exemptions to private foundations established by non-residents. Also I analyse why countries should be interested in changing taxation, even the best approach seems to avoid collecting tax revenues from private foundations. I believe that service fees a country earns and taxes collected from these fees would be substantial enough to make necessary changes to legislation.
\end{abstract}

Keywords: taxation, private foundation, game theory

JEL code: H25, D02, C72

\section{INTRODUCTION}

In history developments of institutions have been both reactive and proactive. At first through social interactions, social behavioural code or social contracts develop. For example, Ken Binmore (2010) defines social contract as "the set of common understandings that allow the citizens of a society to coordinate their efforts". Social contract itself does not need a law as the social system holds it together, however it works until all agents of a social system are motivated to keep the contract. At the point when some agents for selfish reason see a possibility to break the contract the masonry $\operatorname{arch}^{1}$ will likely fall down. This could indicate a point when a legal system is needed to secure the majority from potential damages by some selfish agents.

For example, high net worth individuals need a system to be able to solve their family business continuity and inheritance issues. Historically there were different social contracts, like in some cultures the oldest son inherited everything so continuity of family business was secured. The next development was that trusts were introduced and so this structure was used although trusts were most common in Anglo-Saxon countries. Among family members there is a possibility to agree on a way how to keep family business continuing and healthy, however with more than 1 descendant there is always a risk for conflicting interests. Even if it is possible that sisters and brothers can keep the interests aligned then the spouses who are all most likely "gold-diggers" will make keeping a social contract close to impossible. Hence the need for a special legislation is unavoidable to support the continuity of family businesses in the current economy.

\footnotetext{
${ }^{1}$ A metaphor used by David Hume (1978).
} 
In the end of the last century laws in Europe regulating private foundations for private purposes were introduced ${ }^{2}$.

In this paper I first look for how private foundation platforms satisfy more important concerns and needs of high net worth individuals. Next I give my views in respect of rational choice concept which is necessary presumption for game theory. After that taxation of private foundations is analysed to see whether there is a Nash equilibrium for countries to select a taxation level. Next economic considerations for a country will be presented and the paper ends with an analyses of advantages of Estonia and what the country needs to change.

\section{HIGH NET WORTH INDIVIDUALS AND PRIVATE FOUNDATION}

High net worth individuals is a group which is seen by private banks as a separate client segment. A common definition used (Knight and Frank 2016) is that these are individuals who possess individually investable assets (exclude private residence) more than $\$ 1$ million US dollars. To focus more on the higher end of the group another term ultra-high net worth individuals is commonly used for persons who possess investable assets more than $\$ 30$ million.

Based on Knight and Frank survey (2016) HNWI-s are globally most concerned about family business succession issues, potential increase in wealth taxes and increased scrutiny of wealth by government. Even so private foundations do not address directly the second and third concern, it does directly help to solve the first issue.

Philip Marcovici (2015) lists in his presentation non-tax needs of High Net Worth Individuals among others: business succession, managing risks of divorce, "second" families, "living" wills, asset gathering and identification, family conflict resolution, asset protection and preservation, special assets (art etc.), disability/illness.

Private foundations are used for a large variety of purposes (Sepp and Kaarlep, 2016):

They can be used to prevent the dispersal of the estate (business) after one's death;

They can ensure continuity in management. This could be useful when a founder has no children or if he considers some of his heirs not fit to run the business or they do not wish to do so.

- $\quad$ They can enable the reaching of a specific goal. The familial estate can be assigned to a specific purpose, such as providing for a relative in the case of incapacity or lack of financial maturity. For example, parents with a disabled or minor child may be concerned with who will manage their child's assets, and how they will be managed upon their own death or perhaps when they themselves become disabled. Nowadays, people are tending to live longer, and there is an increase in the number of people who are affected by conditions such as dementia and Alzheimer's disease, which can result in restricted active legal capacity. - $\quad$ Another purpose is to protect specific assets, as in the case of keeping the family home out of the reach of creditors. This could be especially attractive for businessmen or for those whose professions open them up to the risk of civil liability (e.g., doctors or lawyers), but in the light of today's economic and financial instability - and, in some regions, political

\footnotetext{
${ }^{2}$ Whereas in Austria until 1993 foundations had no choice except to be charitable, the Private Foundations Law of 1993 enabled private foundations. In Belgium, the private foundation was introduced in 2002 and the foundation sector in Belgium has been growing since. Malta enacted specific foundation legislation in 2007. The legal and tax landscape on Dutch private foundations dramatically changed with the introduction of a new tax doctrine on 'segregated private capital' as of 2010. Even before that, one specific foundation form, the so-called 'depository foundation' (stichting administratiekantoor, STAK) for the purpose of acquiring and administering assets (shares) was widely used. (Sepp and Kaarlep 2016)
} 
instability - it could be attractive for anyone. It should be kept in mind, though, that there are usually some specific rules protecting creditors in a case wherein a private foundation is set up to harm existing creditors or with no actual change in the control of the property.

- $\quad$ They can also be used to optimize tax liability.

The principal structure of a private foundation is presented on Figure 1.

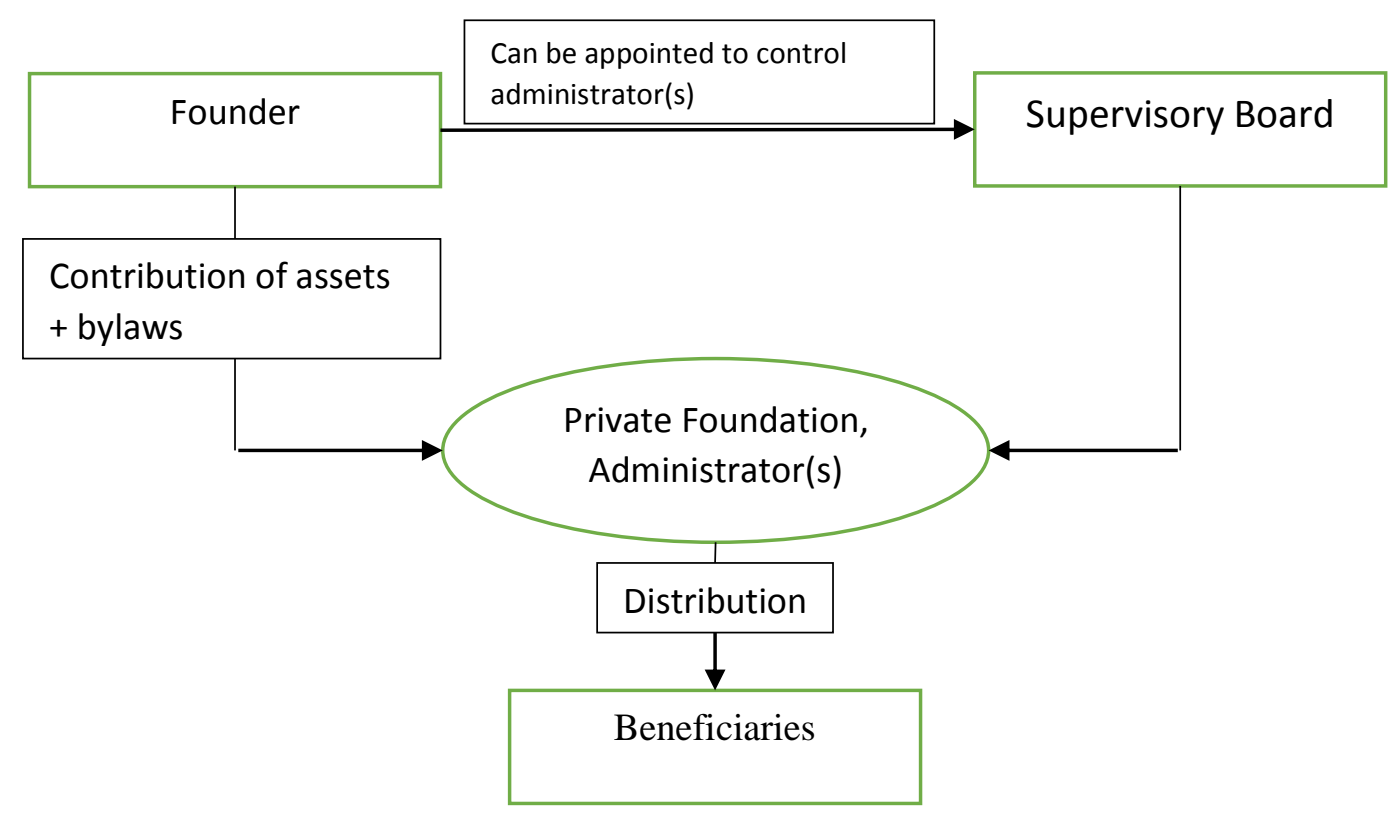

Figure 1. A principal structure of a private foundation

\section{RATIONAL CHOICE AND PREFERENCES}

Rational choice theory assumes that a natural person chooses actions he/she most prefers. Hence the action logic depends on personal preferences. However, where the preferences come and do they stay the same or they evolve? Katznelson and Weingast (2005) build on the insights of Peter Hall (2000) and distinguish three ways preferences can be described and understood. First, assertive theory posits a set of preferences to actors. Second, preferences are determined by historical developments. That means actors will choose their actions based on preferences influenced by their own history and or by history of the group they belong to. Third, preferences are developed through personal relationships and interactions within institutions and or social processes.

All these ways are right, however partially right. For example, strong messages from a person or a group of persons definitely influence preferences although not only. A person can start to avoid to eat meat because an authoritative for him source claims that meat is unhealthy. It seems also true that history influences our preferences although it seems difficult to claim that history is more important than an impact from personal relations and interactions within institutions.

An element that seems to missing in these discussions is impact of personal ego-development. Neoclassical economics assume that individuals maximise their personal utility. It is assumed that actions a natural person makes are determined by self-interest. They are right however partially as this contradicts with adult development theories, for example with constructive- 
developmental theory (Cook-Greuter, 2002; Loevinger, 1976). It can be seen from the research that there are different meaning-making structures and action logics through which adults have the potential to grow. And action logics have significant effect on how individual decision-makers take positions. Natural persons who possess conventional action logic tend to make more selfish decisions while persons with higher level of ego-development are less egocentric in their decisions. Hence the latter group might instead of maximising utility only for themselves (ego-centric preferences) prefer to focus on increasing utility for a social group they belong to (socio-centric preferences) or they want to improve the world (world-centric preferences).

Based on Cook-Greuter (2002) $75 \%$ of US population is in a conventional mind group where selfish behaviour is still dominant. Hence majority of people act based ego driven rational choice based on their selfish preferences. That means rational choice concept can be used for analyses of taxation of private foundations although we need to be aware of its limitations.

\section{TAXATION OPTIONS FOR PRIVATE FOUNDATIONS}

We can look for 3 distinct options how to tax private foundations:

1. To Apply to private foundations similar taxation as to the companies

2. To give exemptions for non-residents in case the origin of income is outside of the country. Sometimes this is called territorial tax system.

3. To introduce tax transparent regime.

The first option means that all income which is taxable at companies will be taxable the same way also at private foundations. In case a country has annual profit taxation and do not have taxation upon distribution it would be a tax neutral system for residents of the country. Which means that HNWI-s of the country can use for their wealth succession either holding company or private foundation and neither of the options have taxation benefits.

Situation gets more complicated in case there is a taxation upon distribution as private foundation is an "orphan" and does not have owners. To keep neutrality between holding company and private foundation structure there is an option to introduce taxation of payments to beneficiaries similar to taxation of distribution to shareholders. However, this would mean double taxation for private foundations who cannot automatically apply participation exemption on dividend income. Companies do not need to pay further tax if distribution is made from the funds received as dividend income and the latter is taxed at a source. To solve the issue we should set that participation exemption on dividend income applies also to distributions to beneficiaries of private foundations.

In respect of the second option for private foundation taxation there would be no difference for income originated in a country and for residents of the country. A different taxation would be applicable only for non-residents and for income originated outside of the country. The system means that exemption is given income originated outside of the country if distributions is made to non-residents. A private foundation would still be legal entity and tax resident of the country which means that also double tax treaties apply.

An issues with this option is that some income (for example some interest income) could be transferred with no taxation which is a thing OECD is trying to fight against with its BEPS (base erosion and profit shifting) program. Another issue is that in case a source country applies withholding tax for example on interest it would not be creditable against tax in a country of beneficiary. 
Third, tax transparent option is different from others as in this case private foundation is still legal entity however it is not anymore tax resident of a country. That means that double tax treaties with other countries would not apply to transactions with a private foundation. All income received by a private foundation will be applied directly to beneficiaries. The option is unlikely attractive to residents as it makes use of private foundation more complicated. For example, even if a private foundation reinvests an income received it triggers taxation at beneficiary level. For non-residents it could be very attractive as in addition to benefits that income outside of the country is not taxable (second option) they could also benefit from double tax treaty between home country of a non-resident and a country where investments were made.

\section{TAXATION OF PRIVATE FOUNDATIONS AND GAME THEORY}

When we define a best taxation regime for private foundations for private purposes we should look at 2 distinct target HNWI groups:

a) Resident HNWI-s

b) Non-resident HNWI-s

If we look the first group, then it seems the best taxation approach is neutral to any other alternative structure. That means:

a) endowments are taxed same rate and timing as inheritance or gifts;

b) net income is taxed as net income of companies;

c) distributions received by beneficiaries on account of founder's endowments are taxed the same rate and timing as gifts or inheritance received;

d) distributions of net income to beneficiaries are taxed the same rate and timing as distributions to shareholders; and

e) distributions received by beneficiaries on account of net income is taxed the same rate and timing as dividends received by shareholders.

Let's try to construct different approach and see what will happen with rational participants of the theoretical "game". I will first analyse the case where the taxation of transaction using private foundation platform is higher or timing is earlier than making the same transactions another way. In this case a decision of the rational player would depend how much he/she is valuing other benefits of using private foundation compared to additional cost involved. In case only the timing would be worse it would be more likely that a founder will use private foundation compared the case when tax rates would be different or the transaction is subject to double taxation. Another case would be when the taxation is lower or timing is later when private foundation platform is used. In this case private foundation form will be used for tax optimisation. Some either business or gift/inheritance transactions would be restructured and private foundation platform will be used for saving or deferring tax cost. This situation would be worse for state budget and would give non-proportional advantages to wealthy people.

The main purpose of the private foundation platform should not be neither to charge higher income for public budget nor give more favourable taxation for wealthy individuals. Rather the aim should be to establish a better legal framework for family wealth succession.

In respect of non-residents we can split the group into two: non-residents who already have made and investment and use a jurisdiction for other purposes (I would call them "old nonresidents"), and non-residents who have not used the jurisdiction before (I would call them "new non-residents"). The best approach for the first group seems very much similar to the group of residents. Except inheritance and gift making are not subject for taxation of the jurisdiction. However, the aim of the taxation approach should not make doing regular 
business through private foundation more favourable for non-residence. Private foundation would give possibility effectively control wealth succession and practically can be also used for carrying business activities although there should be no difference from taxation point of view whether to use private foundation or company platform for business.

A distinctive difference of non-residents who have not use the jurisdiction before would be that they have neither participated in GDP growth neither they have used public goods and services. That means if a country makes a favourable taxation regime for this group there is nothing to lose, only possibility to win. Even if none of the members of this group will use private foundation platform offered, the only thing a country lose is the time and effort to create a platform. And even then the private foundation platform would be still good and beneficial for resident group of HNWI-s. Thus, a country can only win, when non-residents who have not used the country before start to use it.

We can look taxation as a necessary income for state budget to offer public goods and services. The usage of public goods and services by "new non-residence" would be very limited. During their visit to the country they pay their share for transport, hotels and restaurants as tourists. The service they would use, when they want to have a private foundation in a country, would be establishment and keeping the registration in the registry. Hence, the country will set stamp duties for establishment and also could establish an annual fee keeping the private foundation in the registry. These fees would cover cost of keeping registry in the good standing and cost for developing it further. Thus, any service "new nonresidents" will use will be paid by them. And services would not be offered and fees would not be collected in case "new non-residents" would not like the country and would not use the private foundation platform. Thus, even if no additional taxes (taxes are also included in the service fees - VAT for example) are collected from them there would be still positive effect to economic growth and government budget. The amount of taxes "new non-residents" finally pay will depend on their country of residence and the tax system of that country. More about economic reasons to target new non-residents can be found in the next chapter.

Now we look two countries who would target non-resident HNWI-s and establish a private foundation platform. There are multiple selection criteria for HNWI-s to select a location however we will assume for a model that all other criteria would be equal and only taxation determines the preference. Also we assume that people apply rational choice in their decision. Between these countries we can say that there is perfect competition as the product (private foundation platform in a jurisdiction) is exactly the same and only variable is price which is taxation $^{3}$.

Country 1 selects a level of taxation $t_{1}$. For country 2 it would be beneficial to set level of taxation $t_{2}$ lower than $t_{1}$ e.g. $t_{2}<t_{1}$, because it has nothing to lose or there is no income country 2 might not get due to lowering taxation for private foundations. Now country 1 can take its move and for it would be beneficial to lower $t_{1}$ even more so $t_{1}<t_{2}$. This game would continue until both taxation levels are equal to zero $t_{1}=t_{2}=0$.

In game theory Nash equilibrium is a solution concept of a non-cooperative game involving two or more players, in which each player is assumed to know the equilibrium strategies of the other players, and no player has anything to gain by changing only his own strategy. (Osborne, M.J. and Rubinstein, A., 1994).

\footnotetext{
${ }^{3}$ There are also service fees which would be cost for using private foundation platform although I assume for now that these are the same.
} 
It seems zero taxation level is the Nash equilibrium as if one of 2 countries will noncooperative basis increase taxation level private foundations will be established in another country by non-resident high net worth individuals.

\section{ECONOMIC CONSIDERATIONS}

We should ask why a government should bother about establishing a legal instrument like a private foundation (Sepp and Kaarlep, 2016). An answer could be that the country's wealthy voters need this for their family and business succession needs. However, let's assume the number of wealthy voters in the country is so limited that it is not worthy for government to worry about them. We look now for another financial reason why several governments establish the legal instrument.

What a private foundation gives to a country when non-residents will start to use this instrument of the country? We assume that the private foundation will not be involved with trading and other active business and tax neutral taxation approach is applied. It is common that under the private foundation also a holding company will be established (Vogel 2015). The total benefit for the country can be expressed with a formula:

$$
(k+u k) \times(p+t r)+\sum(k+u k) \times\left(t a_{i}+t b_{i}\right) \text { for } i=1, \ldots, n,
$$

where $k$ is the number of families who will establish a private foundation on a country; $u$ is the proportion HNWI-s who also establish an holding company; $p$ represents state fee on establishment per unit; $r$ is a service fee to establish a legal entity; $t$ is a proportion of all tax revenues (VAT, labour taxes and corporate income tax) paid by the companies who render services to these legal entities; $a$ represents annual service fees per entity (domiciliation, management and accounting services which are normally provided by companies who provide trust services); $b$ is annual fees for other services (legal, audit, asset management etc.) per entity; $i$ is a fiscal year and $n$ is a lifetime of the legal entity.

To give an example I try to estimate for Estonia what could be an annual effect for GDP and state budget. I assume the main target markets for Estonian private foundations would be Europe, Russia and CIS and Turkey. And the target client group would be HNWI-s with more than \$10M investable assets (multimillionaires). Based on current numbers there are 205 thousand multimillionaires in the countries mentioned above and forecast for 2025 is 273 thousand. (Knight and Frank 2016) For example, there were in 2011 in Belgium 725 and in 2010 in Austria 2881 private purpose foundations (European Commission 2015). In 2009, the Dutch trust firms served about 16400 clients (though not all were related to HNWI-s), who together held about 20100 legal entities, that is on average 1.2 legal entities per client (Risseeuw and Dosker 2011). For now, we can expect there are more and these were time when due to bank secrecy tax havens were widely used. Based on above I make a conservative estimate that Estonia can attract only 1,000 new non-resident clients who will establish a private foundation. Based on Dutch empirical evidence (Risseeuw and Dosker 2011) it is reasonable to assume that at least $20 \%$ of private foundations establish also a holding company. Current prices for domiciliation, management and accounting services start from 7,200 included VAT (the tax is not reimbursable for private foundation as it cannot be registered for VAT) per entity (Henley Business Services (Estonia) OÜ 2016, Prospera Eesti OÜ 2016). That means in average 7,200 $\times 1.2=8,640$ euros. Based on survey of Dutch trust industry the amount of other services these entities need was in 2009 around $70 \%$ from the 
amount of trust services (Risseeuw and Dosker 2011). If I include also asset management services (these were not included in Dutch survey) the total average fees per investor could easily be 14,000-15,000 euros. If we multiply the result with a number of expected investors we get 14-15 million euros additional GDP. To calculate potential for tax revenue for state budget we use latest officially available total tax revenues of GDP - 32,5\% (Eurostat). That means for state budget at least 5 more million euros for government to spend.

There are other indirect revenues for the country coming from high net worth individuals visits to Estonia not included in the formula above like airport fees, accommodation and restaurant services etc. Elements of the formula are drawn on Figure 2.

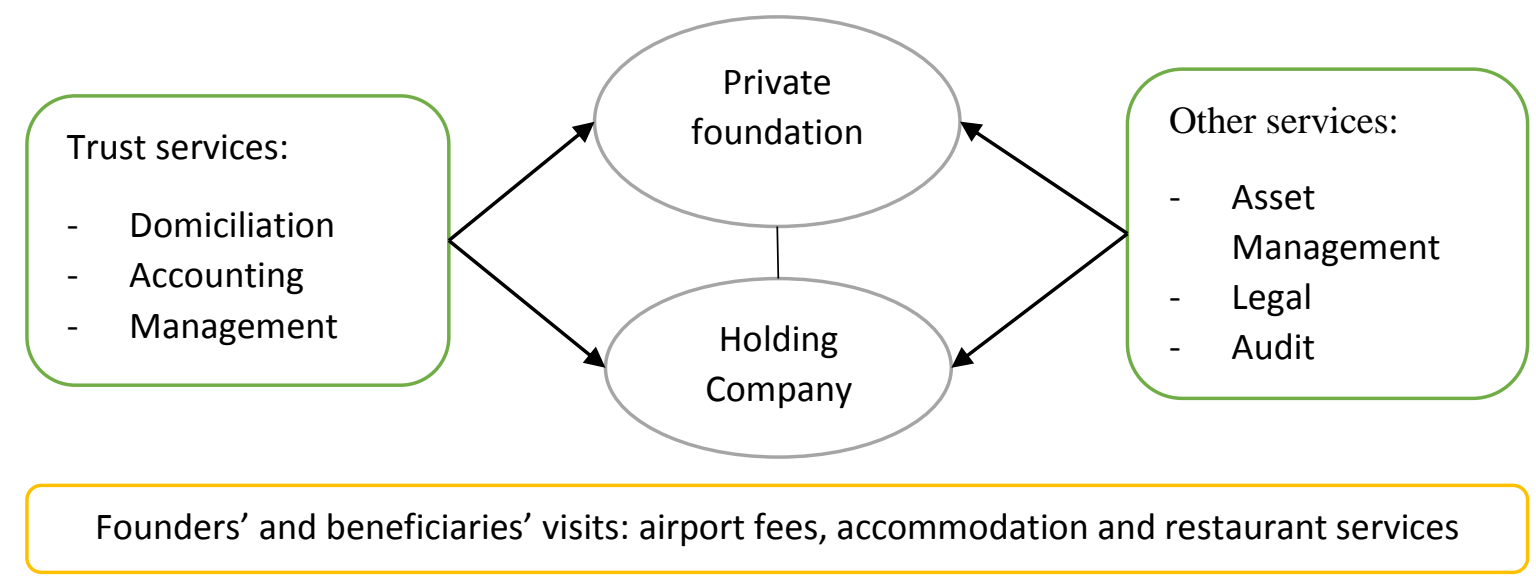

Figure 2. Revenues for resident entities from increasing number of private foundations

\section{WHAT A COUNTRY LIKE ESTONIA SHOULD CHANGE}

There are important points in the current Foundations Act and Income Tax Act which need to be changed or added:

1. Publicity requirements need to be changed to minimum for private foundations for private purposes. It means details of terms of payments to beneficiaries should not be disclosed. Ideally also the data about founder and beneficiaries are restricted to protect their privacy and security. Still requirements of Common reporting Standard and AntiMoney Laundering Directive should be followed. Even so every annual report in Estonia is available to everyone an exception for tax transparent private foundations is very important to make. For those private foundations also audit requirement should be optional.

2. An option to select tax neutral and tax transparent regime would make Estonian private foundations more attractive. That means that companies where the funds are invested will pay taxes in their jurisdiction and beneficiaries pay taxes based on their residence. To avoid risk of double or even triple taxation the private foundation should not be a tax payer as per Income Tax Act.

3. Double taxation in respect of distribution of dividend income and gains from sales of shares should be eliminated. The idea is that transaction flows through foundation should not be taxed differently than transaction flows through company structures.

\section{CONLCUSION}

A distinct group of high net worth individuals is an interesting target for countries who are looking for more foreign direct investments. Based on analyses of the needs of the group one 
of solutions a country can offer is an institution called private foundation. To approach taxation of the platform rational choice concept seems to be better due to that majority of the group will make their pre-selection based on selfish preferences. For taxation of private foundations, a country can use the following approaches: to tax private foundation as companies, to give additional exemption for private foundation or to establish a tax transparent option.

Using rational choice concept, we can apply a game theory to our analyses. When we apply the game theory to analyse taxation of non-resident high net worth individuals the Nash equilibrium would be a zero taxation level. Even so a country will not collect any direct taxes from private foundations it would be still beneficial for the country as it can get GDP growth from additional demand to its service industry. A country like Estonia should adjust some important elements concerning taxation and publicity to make the private foundation platform attractive for high net worth individuals.

\section{References}

Binmore, K. (2010). Game Theory and Institutions. Journal of Comparative Economics. Volume 38, Issue 3, September 2010, pp. 245-252.

Cook-Greuter, S. R. (2002). A Detailed Description of the Development of Nine Action Logics Adapted from Ego Development Theory for the Leadership Development Framework. http://www.cook-greuter.com.

European Commission (2015). Austria Country Report. Eufori Study. European Foundations for Research and Innovation.

http://euforistudy.eu/wp-content/uploads/2015/07/Austria.pdf

European Commission (2015). Belgium Country Report. Eufori Study. European Foundations for Research and Innovation.

http://euforistudy.eu/wp-content/uploads/2015/07/Belgium.pdf

Eurostat. Statistics Explained. Table 1: Total tax revenue by country, 1995-2014 (\% of GDP). http://ec.europa.eu/eurostat/statistics-

explained/images/c/ca/Total_tax_revenue_by_country\%2C_1995-

2014_\%28\%25_of_GDP\%29.png (26.04.2016)

Hall, P. A. (2000). Some Reflections on Preference Formation. Memorandum for the workshop on Rational Choice and Historical Institutionalism. New York: Russell Sage Foundation.

Henley Business Services (Estonia) OÜ 2016. Price list. Internal document. Henley Business Services (Estonia) OÜ.

Hume, D. (1978). A Treatise of Human Nature (Second Edition). Oxford: Clarendon Press.

Katznelson, I., Weingast, B. R. (2005). Preferences and Situations: Points of Intersection Between Historical and Rational Choice In. New York: Russell Sage Foundation.

Loevinger, J. (1976). Ego development: conceptions and theories. San Francisco: JosseyBass.

Marcovici, P. (2015). The Changing Wealth Management World and Opportunities for Henley Trust to Design its Future. Henley Trust Knowledge Weekend, Prague, 19 September.

Osborne, M.J. and Rubinstein, A. (1994). A Course in Game Theory. London, MIT Press. 
Pomerleau, K. and Cole, A. (2015). International Tax Competitivness Index 2015. Tax Foundation.

http://taxfoundation.org/sites/taxfoundation.org/files/docs/TF_ITCI_2015.pdf (26.04.2016)

Prospera Eesti OÜ 2016. Price list. Internal document. Prospera Eesti OÜ.

Risseeuw, P. and Dosker, R. (2011). Trust Matters. The Dutch Trust Industry Revisited. SEO Economic Research.

Sepp, K., Kaarlep, U. (2016). The Estonian Foundation - What Is Missing for It to Be a WellDesigned Wealth-Management Vehicle for Local and Foreign High-Net-Worth Individuals? Juridica International, Vol. 24, pp. 96-104. Tartu: University of Tartu Press.

Vogel, M. (2015). The Dutch foundation: the solution in tax planning, estate planning and asset protection for high net worth individuals worldwide. Trusts \& Trustees, Vol. 21, No. 6, pp. 686-690. Oxford: Oxford University Press. 